\title{
GRACIANO E O PROCESSO MEDIEVAL
}

\author{
Acácio Vaz de Lima Filho \\ Aluno de Pós-Graduação da Faculdade de Direito da USP
}

Resumo:

Neste artigo, tecemos considerações sobre Graciano e a Universidade Medieval, na qual, produziu a sua obra. Tratamos do "Decreto", e de sua difusão, graças à "Escola dos Decretistas" Enfatizamos que Graciano foi um divortium aquarium, na evolução do Direito Canônico, e demonstramos, na esteira de Fernando Della Rocca, que o "Decreto" foi um ponto de partida da evolução que iria dar, ao processo canônico, a sua autonomia.

\begin{abstract}
:
In this article we coment about Graciano and Medieval University whole he brought forth his work. We are discussing "Decreto" and its divulgation, thanks to "Escola dos Decretistas" (Decretista's School). We enphasize that Graciano was a "Divortium Aquarum" in the development of the Canon Law and we demonstrate, in the track of Fernando Della Rocca, that "Decreto" was a starting point in the evolution that would give, to the canonic process, its autonomy.
\end{abstract}

Unitermos: Direito Canônico. Processo Canônico. Universidade Medieval. Sistematização. Bolonha. Estudos jurídicos. Autonomia Científica. Difusão. Decretistas.

Sumário:

I - Introdução

II - Considerações sobre a Universidade Medieval

III Graciano e o "Decreto"

IV A difusão da obra de Graciano. Os "Decretistas"

$\mathrm{V}$ O processo em Graciano

VI Conclusões

VII Bibliografia 
I - Introdução

Como é sabido, no ano de 476 d.C. Odóacro, rei dos hérulos, à testa de uma força invasora, derrubou politicamente o Império Romano do Ocidente, sendo que o mencionado ano de 476 assinala o início da chamada "Idade Média" Enquanto no Oriente o Império Romano vai subsistir até 1453, quando Constantinopla é tomada pelos turcos otomanos, no Ocidente da Europa, no território que fora a "Pars Occidentis" do Império Romano, os povos invasores todos eles, sem exceção, em estágio cultural inferior ao dos romanos vencidos instalam-se nos territórios conquistados, entre eles repartidos, e os governam ao seu modo.

John Gilissen, em Introdução Histórica ao Direito, divide o Medievo em Alta Idade Média, período que vai do século VI ao século XII, e Baixa Idade Média, do século XII em diante. Inclinamo-nos, pessoalmente, por considerar o ano da queda de Constantinopla 1453 como o termo final de toda a Idade Média, e, pois, da Baixa Idade Média. Ainda Gilissen, ao elencar os sistemas jurídicos encontradiços na Europa, do século VI ao XII, entre eles inclui o Direito Canônico (V. ob. cit., tradução de A. M. Hespanha e L. M. Macaísta Malheiros, Lisboa, Fundação Calouste Gulbenkian, 1988, pp. 128-131).

Em termos bastante sintéticos, podemos afirmar que a Unidade Política e Jurídica, que haviam caracterizado o Império Romano, foram substituídas no Ocidente da Europa, na Idade Média, pela Fragmentação Política, e pelo Pluralismo Jurídico. Um outro ponto merece ser destacado: assim como, anteriormente, os romanos vencedores haviam sido subjugados pela superior cultura dos gregos, agora, com a ruína política do Império Romano do Ocidente, os germanos vitoriosos, conscientes da enorme superioridade cultural dos vencidos, irão procurar imitá-los, em tudo. Ou, por outras palavras, o fascínio de Roma e do Império, irá sobreviver à preeminência da "Urbs" enquanto potência militar, política e econômica. Fatos como este, de resto, são bastante comuns na História.

No genuíno caos instaurado com a queda do Império Romano do Ocidente, uma instituição sobrevive incólume. É ela a Igreja Católica. Desde Constantino, $O$ Grande, o próprio Império se tornara cristão. E, assim como Roma, nos anos subseqüentes ao Édito de Milão, ficara impregnada de "catolicidade", a própria Igreja, por sua vez, ficara impregnada de "romanicidade" O Latim tornou-se 
a língua oficial da Igreja; o Papa, antes dos seus outros títulos, ostenta o de "Bispo de Roma" e é chamado, também, de "Sumo Pontífice" ... e assim por diante.

Hannah Arendt, convém lembrar, não hesita em dizer que a Igreja Católica tomou o conceito de Auctoritas, do legado de Roma. Escreve ela:

"O vigor e continuidade extraordinários desse espírito romano ou a extraordinária solidez do princípio fundador para a criação de organismos políticos submeteram-se a um teste decisivo, reafirmando-se indiscutivelmente após o declínio do Império Romano, quando a herança política e espiritual de Roma passou à Igreja Cristã. Confrontada com essa tarefa mundana bem real, a Igreja tornou-se tão'romana' $e$ adaptou-se tão-completamente ao pensamento romano em matéria de política que fez da morte e ressurreição de Cristo a pedra angular de uma nova fundação, erigindo sobre ela uma nova instituição humana de tremenda durabilidade." (v. Entre o Passado e o Futuro, tradução de Mauro W. Barbosa de Almeida, $3^{\text {a }}$ ed., São Paulo, Editora Perspectiva S.A., 1992, pp. 167-68, grifos nossos).

Mais adiante, leciona a mesma autora:

"Graças ao fato de que a fundação da cidade de Roma se repetiu na fundação da Igreja Católica, embora, evidentemente, com conteúdo radicalmente diverso, a tríade romana de religião, autoridade $e$ tradição pôde ser assumida pela era cristã. $O$ sinal mais claro dessa continuidade talvez seja o fato de a Igreja, ao se atirar em sua grande carreira política no século $V$, ter adotado imediatamente a distinção romana entre autoridade e poder, reclamando para si mesma a antiga autoridade do senado e deixando o poder que no Império Romano não estava mais nas mãos do povo, tendo sido monopolizado pela família imperial aos príncipes do mundo". (Ob. cit., p. 169 grifos nossos). 
Por sua vez, a historiadora Barbara W. Tuchman, ao tratar do caos político que se instalou na Europa, após a queda do Império Romano do Ocidente, assim se expressa:

"Depois da queda do Império, a sociedade medieval que surgiu era uma série de peças que não se harmonizavam e se chocavam, sem nenhuma autoridade secular central ou efetiva. Apenas a Igreja oferecia um princípio de organização, e foi essa a razão de seu êxito, pois a sociedade não pode suportar a anarquia." (v. Um espelho distante, tradução de Waltensir Dutra, Rio de Janeiro, Livraria José Olympio Editora S.A., 1989, p. 7 - grifos nossos).

Cremos assistir razão a Hannah Arendt, autora por primeiro citada, quando afirma que a Igreja Católica hauriu de Roma a noção de Auctoritas; segundo pensamos, apenas sendo detentora da Autoridade; poderia a Igreja oferecer, no dealbar da Idade Média, o "princípio de organização" lobrigado por Barbara W. Tuchman ...

Sem dúvida, desempenhou a Igreja Católica, ao longo da Idade Média, um papel relevante ao extremo. Sobre tal papel, escreve o ilustre Nuno J. Espinosa Gomes da Silva, verbis:

"O mesmo condicionalismo histórico que manteve a idéia imperial e favoreceu a ressurreição medieva do Império Romano, explica, igualmente, o chamado renascimento do Direito Romano. Como há pouco se disse - o Direito Romano é o direito do Império.

Ainda que se não entre na análise de todos os factores que se acham na gênese desta situação, não se pode, no entanto, esquecer o papel desempenhado pela Igreja.

Vimos, que, derrubada, politicamente, em 476, a "pars occidentis" do Império, a única grande realidade institucional dos tempos antigos, que sobrevive, e faz a ligação entre o romano e o barbárico é a Igreja. Tempos haverá em que "catholicus" é sinônimo de "romanus". 
Ora, do mesmo modo que foi a Igreja manter a idéia do Império e, depois, a promover a "translatio imperii", assim, também, é ela, que, em contacto permanente com o mundo bárbaro, vai insinuando, nas coisas temporais, a aplicação do Direito Romano que é a sua "lex approbata": a sua "lex saeculi". (v. História do Direito Português, Lisboa, Fundação Calouste Gulbenkian, 1985 , v. I, pp. 140-41 grifos no original).

É fora de dúvida, pensamos, que o fato de ser a Igreja nos primeiros tempos da Idade Média, "a única grande realidade institucional" da Antiguiidade a sobreviver, como nota Nuno Espinosa Gomes da Silva, contribuiu para o seu prestígio, bem como para o papel que desempenhou, de "elo" entre o passado romano e o presente germânico. Mas aduzimos que tanto o prestígio da Igreja Católica à época, quanto o papel relevante por ela desempenhado, seriam inconcebiveis, fora do quadro de estranhada religiosidade do Medievo.

Ao tratar desta matéria, ensina a já citada historiadora Barbara W. Tuchman:

"Na Idade Média, ninguém duvidava que a grande maioria seria destinada à danação eterna. Salvandorum paucitas, damnandorum multitudo (poucos os salvos, muitos os danados) era o rígido princípio mantido de Agostinho a Aquino. Noé e sua família eram tomados como índice de proporção dos que seriam salvos, calculado em geral como um em mil, ou mesmo em dez mil. Não importa que poucos fossem os escolhidos, a Igreja oferecia esperança a todos. A salvação era impossivel para sempre aos que não-acreditavam no Cristo, mas não aos pecadores, pois o pecado era uma condição inerente à vida, que podia ser neutralizado quantas vezes necessário pela penitência e absolvição. 'Volta novamente, volta novamente, ó pecador', dizia um pregador lolardo, 'pois Deus conhece teus descaminhos e não te abandonará. Volta para mim, disse o Senhor, e 
eu te receberei e te levarei para a graça'". (Ob. cit., p.

34 - grifos no original).

É preciso não-olvidar, ademais, o papel desempenhado pela Igreja Católica durante a Idade Média, no que diz respeito à existência quotidiana dos homens da época. A propósito, aduz Barbara W. Tuchman:

"A Igreja dava solenidade e dignidade a vidas que pouco tinham de ambas. Era fonte de beleza e arte a que todos tinham algum acesso e que ajudava muitos a criar. Entalhar as dobras da túnica de um apóstolo, pregar com infinita paciência os brilhantes fragmentos de mosaico até formar um quadro de anjos alados num coro celestial, ficar no espaço imenso da nave de uma catedral entre pilastras que subiam e subiam para uma abóboda quase invisivel, e saber que era obra do homem em honra a Deus era motivo de orgulho para o mais humilde e podia fazer do menor dos homens um artista". (Ob. e loc. cit.).

Razão assiste, sem dúvida, à autora de Os Canhões de Agosto: a religião abrangia, literalmente, todos os aspectos da vida do homem medieval. Assim, não é de causar espécie que os homens da Igreja, na hierarquia social da época, ocupassem o extrato superior. É ainda Barbara W Tuchman quem ensina, verbis:

"A condição de nobreza vinha do nascimento e da linhagem, mas tinha de ser confirmada pela "vida em estilo nobre" isto é, pela espada. Era nobre quem nascia de pais e avós nobres, e assim retrospectivamente até o primeiro calaveiro armado. Na prática, essa norma era falha e a condição, fluída e inexata. $O$ único critério certo era a função ou seja, a prática das armas. Era uma função atribuída ao segundo dos três Estados criados por Deus, cada qual com uma determinada tarefa para o bem de todos. $O$ clero devia 
rezar para todos os homens, o cavaleiro lutar por eles, $e$ o plebeu trabalhar para que todos pudessem comer.

Como o Estado mais próximo de Deus, o clero vinha em primeiro lugar. Dividia-se em duas hierarquias: a que vivia em clausura e a secular, que vivia entre os leigos. Presidiam ambas as hierarquias os prelados abades, bispos e arcebispos, que eram os equivalentes aos grand-seigneurs seculares. Entre o prelado $e o$ padre pobre e semiletrado que vivia de migalhas, pouco havia em comum". (Ob. cit., p. 15 grifos no original).

A intensa religiosidade era, pois, uma das características básicas da Idade Média, senão a mais marcante de todas. Sobre ela, escreve Marcello Caetano:

"Neste fundo de dureza e violência inseria-se a mentalidade religiosa. $O$ homem medieval era profundamente religioso e o português da Reconquista não fugia à regra. Religião em geral pouco esclarecida, mas que penetrava, até ao âmago na vida individual $e$ colectiva.

Vivendo numa natureza indômita, de uma agricultura sujeita a todos os riscos as intempéries, as calamidades cósmicas, as epidemias, a doença e a morte, tudo constituía para a humanidade um mistério, cujas manifestações irresistiveis eram comandadas pela Divina Providência e de que só pelo milagre às vezes os indivíduos se podiam salvar. À fé profunda em Deus, juntava-se assim a certeza do governo da sua Providência e a esperança constante no milagre.

Esse milagre não o poderiam merecer os homens senão pela penitência e pela comunhão dos santos, isto é, pelo facto de cada cristão aproveitar os méritos de Cristo e de todos os que na cristandade obtivessem para o Mundo a graça divina. Por isso, ao lado da violência se encontra na Idade Média a santidade na sua forma mais exaltada (S. Francisco de Assis é um protótipo) e 
uma preocupação colectiva permanente de aplacar as iras divinas, nas procissões, nas romarias e nas grandes peregrinações aos santuários". (V. História do Direito Português, Lisboa, Editorial Verbo, 1981, v. I, pp. 199200 -grifos nossos).

Prossegue o ilustre professor da Universidade de Lisboa, verbis:

"O homem, aliás, tinha pouco apreço pelo seu corpo e pelo seu bem-estar. A vida era curta, e consistia em breve passagem pela Terra a caminho da eternidade. $O$ receio do juízo divino depois da morte é um dos raros e mais fortes travões do procedimento humano. Juízo individual, e o grande e colectivo Juízo Final, tão freqüentemente representado na arte medieval.

Sem ter presente esta mentalidade não poderão compreender-se a influência do clero e muitíssimos, aspectos do Direito da Idade Média: desde a redação dos documentos, com suas "arengas" teológicas e suas fórmulas de maldição, até ao sistema das provas judiciais, com o "juízo de Deus". (Ob. e loc. cit. - grifos nossos).

Como vemos, tendia o homem do Medievo a vislumbrar, nos mais variados fatos, a intervenção direta da Divindade. Este dado não escapou a Sir Arthur Conan Doyle, o notável escritor escocês que dedicou algumas das suas obras de ficção histórica à temática da "Guerra dos Cem Anos" Escreve Conan Doyle, em A Companhia Branca:

"Aleine Edricson inclinou a cabeça enquanto o abade elevava sincera súplica ao Céu para que guardasse a alma dêsse jovem que se embrenhava nas trevas e perigos do mundo. Não era simples formalidade para nenhum dêles. Para êles a vida exterior se afigurava de violência e pecado, cheia de perigos físicos $e$, mais ainda, de perigos espirituais. $O$ céu também naqueles dias estava muito perto dêles. Viam 
manifestações diretas de Deus no trovão e no arco-íris, nos tufões e nos relâmpagos. Para o crente, nuvens de anjos, confessores e mártires, exércitos de santificados e remidos estavam sempre dirigindo os irmãos que lutavam na terra, erguendo-os e amparando-os." (Cf. ob. cit., São Paulo, Edições Melhoramentos, s/d, p. 25 grifos nossos).

Cremos estar suficientemente ilustrada a entranhada religiosidade da Europa Medieval, a qual, aliada à circunstância de ter a Igreja Católica remanescido, nas palavras de Nuno J. Espinosa Gomes da Silva "a única grande realidade institucional dos tempos antigos" (ob. e loc. cit.), permitiu que o Direito Canônico e, de conseguinte, o Processo Canônico - tivesse, neste longo período histórico, a preeminência que ostentou.

O labor de Graciano se desenvolveu na Universidade de Bolonha. Ora, a instituição universitária, como é sabido, nasceu e se consolidou na Idade Média. Destarte, cremos oportunas algumas considerações pertinentes à Universidade, o que faremos a seguir.

\section{Considerações sobre a Universidade Medieval}

Ainda não desapareceram de todo da literatura científica o que é lamentável - os efeitos deletérios dos preconceitos que, contra a Idade Média em geral, foram difundidos pelos historiadores do Renascimento. Assim, ainda é comum que, ao Medievo, sejam atribuídos os qualificativos de "Idade das Trevas" (Dark Age), "Período do Obscurantismo" e assim por diante.

O estudioso da História deve se acautelar contra o perigo de tratar o passado, utilizando-se dos padrões do presente. E esta cautela, segundo pensamos, deve ser redobrada no estudioso da História do Direito.

Em se tratando da Idade Média, é preciso ter em mente, no trato das suas instituições, a advertência candente do professor Marcello Caetano, que transcrevemos "retro" na "Introdução" De plano, fique consignado que não podemos e não devemos concordar com o nome de "Idade das Trevas", aplicado a uma época que produziu a própria Universidade, cuja gênese medieval teremos 
forçosamente que conhecer, sob pena de renunciarmos a compreender a instituição universitária, tal como hoje ela se nos apresenta...

Antonio Garcia y Garcia, em seu notável livro Estudios sobre la Canonística Portuguesa Medieval, faz uma análise cientificamente séria do tema em apreço.

Após tecer algumas considerações sobre as causas do surgimento das Universidades a partir do século XII, Garcia y Garcia assim se manifesta sobre Bolonha:

"El papel que jugó Bolonia en el mundo del derecho medieval puede sugerir al lector menos avisado la idea de que se verificó el trasplante de una institución italiana a toda la Europa de entonces.

Pero en realidad la escuela de derecho de Bolonia era internacional, porque lo eran las fuentes constitutivas de ese derecho y lo eran también los maestros y alumnos de las aulas boloñesas. En este sentido, Bolonia era menos italiana que Roma, La gloria de Bolonia va ligada a su universalismo y a la presencia de extranjeros enm el professorado y alumnado.

Cuando esta presencia decae a finales del s. XIII, declina también el prestigio boloñés. Esta presencia internacional decae principalmente por dos razones: el surgir de otras universidades por toda Europa y las medidas contra el elemento forastero en Bolonia". (V. ob. cit., Madrid, Fundacion Universitaria Española, 1976, p. 20).

Ao relacionar o surgimento das Universidades com a aparição dos juristas, escreve o autor espanhol:

"Con el nacimiento de las universidades coincide la aparición de los juristas, que con su actividad científica juegan un papel realmente importante en la vida de aquella sociedad. 
Recuérdese que el derecho constituye uno de los principales ingredientes de la vida social en la edad media, de suerte que nunca se podrá interpretar correctamente la historia medieval sin un conocimiento a fondo del factor jurídico, como resultaría sin sentido la historia contemporánea de estos últimos siglos sin tener muy presente el factor económico" (Ob. cit., p. 21 - grifos nossos).

O autor ora examinado, após reconhecer que a Universidade se encontra, atualmente, em crise, põe como condição primeira para uma reflexão serena sobre o assunto, o conhecimento do que chama de "lógica interna" que informou a instituição universitária, desde os seus começos.

Fixemos bem um ponto. Garcia y Garcia distingue entre o que chama "Universidades Hierárquicas" e "Universidades Democráticas". As de Paris e Oxford estariam entre as primeiras, ao passo que Bolonha estaria entre as segundas. Para os objetivos do presente estudo, o fundamental é saber como se desenvolviam os estudos de Direito Canônico na Universidade de Bolonha. Deixaremos de lado, propositalmente, as interessantíssimas questões alusivas aos estatutos e ao funcionamento da Universidade como um todo, limitando-nos a afirmar, com segurança, que a instituição universitária na Idade Média, usufruiu de uma autonomia jamais igualada a posteriori.

A autonomia da Universidade no Medievo é essencial para a sua compreensão, sem dúvida. Mas, a esta autonomia, é imprescindível que o estudioso contemporâneo acrescente uma outra característica básica, que muito contribuiu para a grandeza da instituição. Referimo-nos ao compromisso com o saber pelo saber, que é a antítese do utilitarismo e do imediatismo, que corroem a Universidade contemporânea.

Feitas estas considerações introdutórias, estamos habilitados a examinar como se desenvolviam os estudos canonísticos na Universidade Medieval, de que Bolonha é o paradigma. 
Ensina Garcia y Garcia:

"Los textos legales objeto de estudio en la universidad medieval eran fundamentalmente los dos Corpus Iuris, civil y canónico. A las colecciones del Corpus Iuris Canonici hay que añadir algunas colecciones intermedias como les así llamadas Compilaciones Antiquae, el Concilio IV Lateranense de 1.215 , las colecciones de decretales de Inocencio IV y Gregorio X, aparte de algunas decretales sueltas como la decretal Cupientes de Nicolao III. A las Compilationes Antiquae se las denomina Decretales Antiquae en oposición a las Decretales Novae (Liber Extra) y a las Decretales Novissimae o Novellae (diversas colecciones intermedias). A veces no aparece claro si alguno de los escritos sobre estos textos adicionales son fruto de la docencia universitaria u obra de laboratorio sin relación directa con la actividad universitaria. Tenemos, pues, que por lo que respecta a la cononística, se comentaba en clase el derecho canónico vigente tal como aparecía en las más recientes colecciones y a veces incluso antes de que entrara a formar parte de colección alguna. En este último sentido se aludía a los textos legales con la fórmula extra omnes titulos". (Cf. ob. cit., p. 41-2 - grifos no original).

Deixamos de mencionar os textos estudados pelos civilistas (romanistas), uma vez que a nossa atenção ora está voltada para o Direito e para o Processo Canônicos.

No que diz respeito à metodologia, deve ficar consignado que as lições dos professores, recebiam o nome de "lectiones", ou "lecturae". Consistiam elas, fundamentalmente, no comentário ao texto legal. Era seguido, aqui, o método preconizado por Hostiense na "Summa Aurea" (X 5.5). Escreve, a propósito, Garcia y Garcia: 
"O sea, que en primer lugar se fijaba el sentido del texto, se aducían los lugares paralelos, razones en pro y en contra, cuestiones que se derivaban del tema central, notabilia y conclusión o punto de vista del profesor" (Ob. cit., p. 45 grifo no original).

Um outro exercício era o das "repetitiones" (repetições), que consistia, geralmente, em um exame mais exaustivo de textos legais que já haviam sido objeto do comentário ou curso ordinário. Às vezes, a repetição se limitava a uma recompilação de elementos muito díspares sobre um determinado tema.

Além destas repetições feitas por professores havia outras, feitas pelos estudantes.

Na Universidade de Bolonha - sempre de acordo com o jurista espanhol já citado - ocorriam na primavera e no verão as "disputationes". Delas, diz Garcia y Garcia que "consistían fundamentalmente en la discusión pública de una cuestión jurídica que se elegía arbitrariamente o se tomaba de la vida real o de los tribunales." (Ob. cit., p. 46).

Das "disputationes" em Bolonha, só podiam participar os doutores. Mas, a todos os assistentes, era facultado objetar, oferecendo "oppositiones" Se os assistentes objetassem "por ofício", recebiam o nome de "concorrentes".

Refere Garcia y Garcia que o "Libellus Disputatorius" de Pillius de Medicina, e o "Modus Arguendi". de Dino de Mugello, são protótipos desta literatura, destinada a fomentar nos estudantes de Direito a habilidade dialética. Há coleções de "Quaestiones Disputatae" que chegaram aos nossos dias.

Apresenta cremos algum interesse acadêmico, saber algo da rotina letiva de Bolonha, que, repitamos, no que tange aos cursos jurídicos, serviu de paradigma para as Universidades fundadas a posteriori. Escreve Garcia y Garcia:

"Los canonistas comenzaban sus clases en Bolonia el día siguiente de San Lucas (19 octubre) y los civilistas al dia siguiente. El curso duraba un año. Pero había unos 90 días de vacación: 11 por Navidad, 15 por Pascua de Resurrección y unos dos meses en verano. Si no había ningún día festivo durante la semana, el jueves era día de vacación. La clase ordinaria comenzaba al alba (ad Primam), durando de dos a tres horas. Esta clase era 
dada por profesores ordinarios. Las clases extraordinarias tenían lugar por la tarde, comenzando a las tres y terminando después de Visperas (hacia las 5 de la tarde). Las repetitiones y disputationes comenzaban hacia las 5 de la tarde y se prolongaban por espacio de una hora u hora y media." (Ob. cit., p. 47).

Dois detalhes saltam à vista. Em primeiro lugar, a Idade Média era, por excelência, madrugadora. A iluminação artificial era deficiente e dispendiosa. Assim, urgia aproveitar, ao máximo, a luz do sol. As aulas principiavam ao alvorecer (Ad Primam). Em segundo lugar, o Curso de Direito era, como o diríamos hoje, um curso "de período integral". Por derradeiro, há a presença, também aqui, do elemento religioso, aliás, onipresente na Idade Média: as aulas extraordinárias terminavam "depois das Vésperas"...

As aulas eram todas ministradas em Latim. Os "pontos" foram uma novidade introduzida pouco após a metade do século XIII. Objetivavam evitar que, do texto legal, ficassem partes por explicar. Escreve Garcia y Garcia, verbis:

"Estos puntos (puncta) dividen cada libro legal en varias partes indicando en qué tiempo había que explicar cada una." (Ob. cit., p. 48 grifo no original).

Mais adiante, prossegue o jurista espanhol:

"En Bolonia, la tasación o determinación de la extensión y contenido de cada punto era hecha por los doctores y escolares designados por el Rector. Podían cambiarse según la conveniencia, por lo que no aparece ninguna tasación concreta en los estatutos boloñeses. Los profesores estaban obligados a observar estrictamente los puncta tanto por lo que se refiere al contenido como al tiempo de duración. La legislación de los estatutos universitarios medievales sobre los puntos era verdadeiramente puntillosa. Al concluir cada punto, había que anunciar el seguiente. 
Los estatutos prevén varias penas para los profesores que no cumplían los puntos. El notario debía puncta per universitatem taxare, legere et publicare per scolas omnium ad puncta legentium ea die, qua punctus completur. Ningún profesor podía explicar más de un punto cada día. No se podían modificar, quitando algún capítulo, ley o párrafo que figurase en el punto del día en cuestión. Tampouco se podía explicar dentro del punto de cada día otros textos legales que no estuvieran comprendidos en dicho punto." (Ob. cit., p. 48-9 grifos no original).

Como se pode perceber, esta minuciosa regulamentação está em total concordância com o que podemos chamar de "espírito da Idade Média"

Observa Garcia y Garcia que a duração do "curriculum studiorum" em Bolonha, variou no decurso do tempo. Por volta de 1300, eram necessários sete anos para o doutorado em Direito Civil (isto é, Romano), e cinco para o doutorado em Direito Canônico.

É interessante, pensamos, consignar aqui algumas informações sobre os exames e os graus conferidos pela Universidade. A propósito, escreve Garcia y Garcia, verbis:

"En Bolonia no había un examen correspondiente a cada curso académico. El único título al que estaban ordenados todos los estudios y exámenes era el de doctor o maestro, llamado más adelante laurea. Los estatutos precriben cinco cursos de leyes para leer o explicar un título o tratado secundario y seis para la lectura de un libro legal entero. En derecho canónico, se requerían, respectivamente, 4 años para un título y 5 para un libro completo. Después de haber enseñado durante un año un libro entero en calidad de bachilleres (nótese que no había examen de bachillerato), se les consideraba aptos para el examen de licencia". 
Al principio posiblemente hubo único examen, que era el de doctorado. Pero pronto se registran dos pruebas. La primera debía sostenerla el candidato ante la comisión de profesores y la segunda ante el Colegio de Doctores. Desde fines del s. XIII ambas pruebas tuvieran lugar ante el mencionado Colegio. La primera prueba debía conducir a la licentia docendi, y esta era la prueba sustancial verdaderamente demonstrativa del grado de conocimientos del candidato. La segunda, llamada conventus o conventatio consistía fundamentalmente en la ceremonia de colación del doctorado. Aunque es una prueba más protocolaria que esencial, se exigía absolutamente como condición para poder ejercer el título de doctor. Antes de la licencia, se le señalaban al candidato los puncta que debía comentar, que eran para los canonistas un capítulo del Decreto y otro de las Decretales". (Ob. cit., p. 51 grifos no original).

Aprovado o estudante, recebia a "licença" Esta, em Bolonha, não implicava na "licentia ubique docendi". Para obter esta última, era preciso que o estudante obtivesse o doutorado.

Anota o jurista espanhol ora seguido, que o exame de "licença" era "o mais substancial", e também "o mais duro" (Ob. cit., p. 52). E aduz que a colação do grau de doutor era uma cerimônia cheia de solenidade e mais protocolar do que efetiva, no que dizia respeito ao exame dos conhecimentos e à competência do candidato.

Esta cerimônia a da colação do grau de doutor - ocasionava grandes despesas, sendo que, assim, muitas vezes, o grau de doutor era conquistado, mais em função das riquezas do candidato, do que do seu saber.

No que tange à procedência social dos estudantes, informa o jurista espanhol ora seguido que os estudantes, na Idade Média, procediam de todas as classes sociais. Escreve a propósito:

"Entre los estudiantes aparecen, en efecto, miembros de familias del mundo de la nobleza, de la caballería, de 
las armas, de la administración, del comercio, de la agricultura, de las más variadas profesiones y del proletariado. La clase social más ampliamente representada es la burguesía." (Ob. cit., p. 55).

Os clérigos eram mais numerosos do que os leigos. Mas, adverte Garcia y Garcia, é preciso ter em conta que muitos recebiam a tonsura, apenas para poder desfrutar de um benefício eclesiástico que lhes permitisse pagar os estudos, sem que depois seguissem a carreira eclesiástica. Lembramos, a propósito, que este expediente era muito frequiente no Medievo, em função da vasta gama de regalias concedidas ao clero...

Em Bolonha, os Estatutos da Universidade não especificavam os requisitos prévios, exigidos aos estudantes, para cursar a Universidade. Mas alguns autores aludem à instrução nas "artes liberais"

Há um dado que consideramos de grande interesse, porquanto desmente o mito - desafortunadamente correntio! de que a Sociedade Medieval, "fechada" não-permitia a mobilidade social. Nós nos referimos à questão do financiamento dos estudos, para os estudantes pobres. Aqui, como alhures, decisivo foi o papel desempenhado pela Igreja Católica. Escreve o jurista espanhol, verbis:

"Ante todo, hay que advertir que los poderes públicos no se ocuparam de este aspecto, limitándose generalmente a garantizar en esta materia lo que organizaba la Iglesia. Esta última fue la que créo un sistema de protección escolar a favor de los alumnos necesitados de ayuda económica para proseguir sus estudios.

Al revés de lo que ocurrió con la sociedad clasista de épocas posteriores, en la edad media no eran prevalentemente los ricos quienes estudiaban" (Ob. cit., p. 59 - grifos nossos).

É preciso ter um extremo cuidado, nos estudos históricos "in genere", para obviar o perigo de aplicarmos ao passado os parâmetros do presente. Feita esta ressalva, e bem imbuídos do mencionado cuidado, cremos ser lícito afirmar que a Universidade Medieval era muito mais democrática do que a atual. É o que podemos 
extrair da seguinte lição do autor de "Estudios sobre la Canonistica Portuguesa Medieval":

"Todo lo dicho constituye una evidencia de que en las universidades de tradición boloñesa los estudiantes participaban activamente en lo más esencial de la vida universitaria, que condicionaban en gran parte con su voz $\boldsymbol{y}$ voto. Ellos elegían a los consiliarios, quienes a su vez nombraban al Rector y le asesoraban en el gobierno de la universidad unas veces com voto consultivo y otras deliberativo. Su voto pesava igualmente en la elección de profesores. Incluso el profesor o maestro que cada estudiante debía tener por prescripción de los estatutos como director especial de sus estudios, era elegido por cada escolar y no impuesto por las autoridades académicas". (Ob. cit., pp. 62-3 grifos nossos).

Não havia, como na atualidade, um planejamento para a utilização das chamadas "horas de lazer" Em função disto, era maciça a presença dos estudantes aos atos acadêmicos, que ostentavam um ritual realmente solene.

Ainda, a propósito da participação dos estudantes na vida universitária, há um dado importantíssimo, ao nosso ver: - Os livros eram muito caros, antes da invenção da imprensa. Destarte, a transmissão oral do saber, possuía uma relevância que, hoje, mal podemos avaliar. Fácil é deduzir, daí, que um estreito relacionamento entre professores e alunos, assinalava a Universidade Medieval.

Os estudantes, como é sabido, gozavam de foro especial, circunstância que suscitava muitos litígios entre eles e as autoridades municipais. Em Bolonha, isto ocasionou, freqüentemente, a intervenção do Papa, ou do Imperador.

A destinação dos estudantes, após terminados os cursos, apresenta um grande interesse cultural. Uma minoria desses alunos se incorporava à docência, na própria Universidade de Bolonha, ou ainda em outras Universidades. Mas a maioria, de volta aos respectivos países de origem, ocupava cargos importantes, nas chancelarias civis ou eclesiásticas. Ora, os antigos alunos de Bolonha, tendiam, como é óbvio, a pôr em prática o Direito Comum Medieval, aprendido na Universidade, ao invés do Direito Local do país de origem. E este foi um dos mais 
importantes fatores de penetração do Direito Comum Medieval, Romano-Cacônico, nos ordenamentos locais ou nacionais de muitos territórios.

Ora, como vimos retro, a Igreja, única grande realidade institucional a sobreviver à Antigüidade, foi a legatária do Império Romano, de quem hauriu a noção de Auctoritas. Foi ela, no dizer feliz de Nuno J. Espinosa Gomes da Silva, o "elo" entre o romano e o barbárico. E é a Universidade, nascida sob o manto protetor da Igreja Católica, que, legatária do saber antigo, vai contribuir, decisivamente, para que o Direito Romano-Canônico seja recebido em praticamente toda a Europa.

Estas considerações sobre a Universidade, a sua gênese, e a sua evolução, não são ociosas em um trabalho pertinente à História do Processo Canônico, como poderia parecer prima facies. Em primeiro lugar, há de se levar em conta que os estudos sistemáticos do Direito e do Processo Canônico, seriam inconcebíveis fora do contexto da Universidade Medieval. Em segundo lugar, não existem causas isoladas, e nem efeitos isolados, naquilo que Miguel Reale, chama, com acerto, de "Mundo da Cultura" (cf. Lições Preliminares de Direito, 16 ${ }^{a}$ ed., São Paulo, Saraiva, 1988, pp. 9 e ss.). O Direito integra este "Mundo da Cultura", de que fala o insigne jusfilósofo patrício. Nele, não há causas. Há sim, e ao revés, "concausas" que desembocam nos fenômenos. Em terceiro lugar, é o Direito um fenômeno histórico e cultural. A historicidade lhe é intrínseca. E o corolário desta assertiva é o de que, para bem conhecer a obra de Graciano, é mister conhecer a espaço-temporalidade em que ela foi produzida. Ora, tal obra foi levada a cabo, no fascinante Mundo da Universidade Medieval, com as suas "nações", o seu complicado cerimonial, os seus códigos de honra, e assim por diante. Por fim, nunca é ociosa - parece-nos - uma reflexão sobre a temática universitária. Nos momentos de crise de uma instituição, nada é mais salutar do que um "mergulho" nas suas origens... a propósito se expressa Antonio Garcia y Garcia com grande acerto:

"Finalmente, la universidad es una institución que recibimos del medievo. Una institución de vital importancia como esta, estuvo sujeta entonces y está ahora a las tensiones y crisis propias de todas las manifestaciones importantes del espíritu humano. Historia y presente pocas veces se hallan tan intimamente relacionados como en este tema. La reflexión sobre esta temática desde sus orígenes no es superflua nunca y mucho menos a la hora de querer dar 
pleno sentido a la institución universitaria de los tiempos en que vivimos. Creo resultará útil tratar de revivir, como en el psicoanálisis, el proceso vital que corre desde la infancia de la institución universitaria hasta su actual situación crítica" (Ob. cit., p. 65 - grifos nossos).

III - Graciano e o "Decreto"

Como observa Antonio Garcia y Garcia na obra já citada, o fator jurídico desempenhou um papel preponderante na Idade Média; um papel comparável ao desempenhado pelo fator econômico em nossos dias. Como se isto não bastasse, foi de grande relevo o papel da Igreja Católica no Medievo. E também, acrescentaríamos, o do Direito da Igreja, vale dizer, o Direito Canônico. Assim, não é de causar estranheza que o Dicionário da Idade Média, organizado por $\mathrm{H}$. R. Loyn, obra, aliás, não-especializada em Direito, dedique um verbete ao monge Graciano, o qual assim se insculpe:

"Graciano (m. c. 1.179). Um dos maiores juristas da Idade Média, estudou nas escolas de Bolonha, aplicou tanto o novo saber baseado no Direito Romano quanto os avançados métodos dialéticos de seu tempo na criação de um compêndio de valor permanente para o direito da igreja, conhecido como o Decretum (1.13940). Seu título original para essa obra foi Concordantia Discordantia Canonum (Concordância de Cânones Discordantes); apoiou-se consideravelmente na autoridade dos Santos Padres, nos Concílios e nos decretos de imperadores e papas. Forneceu uma ordenação sistemática e atualizada do direito canônico e tornou-se rapidamente um auxiliar infalível e essencial na formação e prática dos juristas canônicos. Como tal, era avidamente aproveitado pelos papas e, na verdade, reflete as aspirações legais do Papado reformado do 
século XII. Graciano, monge do credo camaldunense, foi feito cardeal pelo papa Alexandre III". (V. ob. cit., tradução de Álvaro Cabral, Rio de Janeiro, Jorge Zahar Editor, $2^{\text {a }}$ ed., 1991, p. 171 - grifos nossos).

No verbete dedicado à Universidade de Bolonha, o já-mencionado Dicionário volta a mencionar Graciano, como podemos aferir da transcrição abaixo:

"Bolonha, Universidade de Fundada no século XI em conseqüência do ressurgimento do interesse pelo estudo do direito, a fama de Bolonha era tão-grande em meados do século XII que o imperador Frederico I convocou seus doutores em leis a Roncaglia para emitirem um parecer em seu conflito com as comunidades lombardas. À semelhança da Universidade de Paris, a de Bolonha estava organizada em nações $e$ em 1265 estas incluíam estudantes vindos de países tãodistantes como a Inglaterra, a Polônia e a Hungria. $O$ prestígio de Bolonha baseou-se principalmente na obra de dois homens: Irnério, que por volta de 1080 separou o estudo do direito das outras artes, e Graciano, que em 1140 unificou o direito canônico em seu Decretum e o distinguiu da teologia. Honório III concedeu à Universidade um certo grau de autononia em 1218 e mais adiante, nesse mesmo século, lá começou a se desenvolver uma notável escola de medicina" (Ob. cit., pp. 54 e 55 - grifos no original).

Enfatizemos: O Dicionário da Idade Média, ora citado, não é uma obra especializada em Direito, o que, segundo cremos, demonstra a enorme importância de Graciano e do "Decreto" na Cultura do Medievo.

Por fim, no verbete "Direito". o Dicionário em epígrafe, a um tempo, evidencia a já-mencionada relevância do fator jurídico na Idade Média, e faz menção a Graciano e ao "Decreto". Abaixo, transcrevemos as partes, mais importantes para o nosso tema, do verbete em pauta. 
"direito O império da lei é um dos mais poderosos conceitos legados pelo mundo medieval ao mundo moderno, mas suas origens são complexas, provenientes de raízes tanto germânicas quanto latinas." (Ob. cit., p. 118 - grifo no original).

"O direito canônico desenvolveu-se por caminhos próprios, e o gênio de Graciano, no começo da década de 1140, colocou a lei da igreja numa nova base metodológica. Sua Concordância dos Cânones Discordantes tinha uma imensa dívida com a Escola Bolonhesa". (Ob. cit., p. 119 - grifos no original).

"No nível teórico, a teologia e o direito estavam intimamente interligados. No século XIII foram introduzidos refinamentos de maneira sumamente sutil e efetiva por Santo Tomás de Aquino - nas idéias básicas de Santo Agostinho a respeito da relação entre o direito divino (revelado pela fé), o direito natural e o direito positivo. A política, a teoria política e o estudo do direito também eram parceiros íntimos, e muitos dos grandes mestres juristas do final da Idade Média envolveram-se ativamente em controvérsias sobre o fim do Grande Cisma e o movimento conciliar. Conceitos de soberania e de utilitas pública foram formulados pelos juristas romanos. A disciplina de direito persistiu academicamente como uma das mais gratificantes, nas acepções intelectual e prática da palavra. Organizado em universidades, como a de Bolonha, ou nos Inns of Court ingleses, o estudo do direito exerceu um poderoso e permanente efeito sobre a vida intelectual da Europa" (Ob. e loc. cit., grifos no original). 
Jean Des Graviers, em seu Le Droit Canonique, elenca o Decreto de Graciano entre as que chama de "Coleções Sistemáticas" (de Direito Canônico) da Idade Média. Como o autor compara a atividade de Graciano com a de Yves de Chartres (Santo Ivo), julgamos ter algum interesse acadêmico a transcrição abaixo:

"Gratien était un moine de Toscane qui enseignait le droit à Bologne. La collection qu'il publia vers 1140 dépasse celle de tous ses devanciers, sauf le Décret d'Yves de Chartres, par le nombre des textes (3500 fragments). Par la méthode elle leur est grandement supérieure car Gratien applique les procédés qu'Yves de Chartres avait seulement énoncés dans as Préface en laissant au lecteur le soin de les utiliser" (Cf. ob. cit., Paris, Presses Universitaires de France, deuxième édition mise a jour, 1967, p. 41 grifos nossos).

Como podemos perceber, o autor - um mestre francês - ao falar de Graciano, não resiste à tentação de compará-lo com um outro canonista... francês!...

Ao abordar o "Decreto". in se ipso, Jean Des Graviers relata o método seguido por Graciano na sua elaboração, e realça, outrossim, os atributos do "Decreto". enquanto livro didático.

Escreve o jurista francês, verbis:

"Les textes de Gratien sont presque tous empruntés à des collections antérieures. A côte de chaque fragment se trouve l'indication, exacte ou non, de son origine. Les canons des conciles et les décrétales des papes sont les principales sources; c'étaient de véritables textes législatifs. Comme ses devanciers, Gratien y joint des passages de la Bible des citations des Pères de l'Eglise, des extraits de recueils ecclésiatiques officiels, comme les livres liturgiques et le Liber diurnus, ou privés, comme des pénnitentiels et des ouvrages historiques; il reproduit des textes du droit romain, des capitulaires des rois francs et des fausses décrétales.

Le nombre seul de ces extraits ou "canons" aurait suffi à rendre inutile le recours aux autres collections 
italiennes largement dépassées. Mais l'ordre dans lequel les textes étaient présentés et les explications personnelles de l'auteur (dicta Graciani) avaient plus de prix encore. Le but de Gratien n'était pas seulement de rassembler presque tous les textes canoniques alors connus. Il les interprétait en disposant l'un prés de l'autre les textes concernant un même sujet et lorsqu'ils divergeaient en indiquant pourquoi l'un devait être préféré à l'autre, soit en raison de l'autorité $d u$ législateur, soit en raison des conditions de date, de lieu, de circonstances qui réduisaient l'autorité du second. C'est pour manifester ce but qu'il avait, semblet-il, intitulé son ouvrage Concordia discordantium canonum. Mais la postérité lui donna le titre des deux ouvrages les plus célèbres jusqu à cette époque, le décret de Burchard et celui d'Yves de Chartres: on appela son oeuvre Le décret de Gratien et plus absolument encore Le Décret. Pendant un siècle as collection allait devenir à Bologne, à Paris, dans les autres universités, la somme du savoir canonique, le manuel des étudiants, le livre que commenteraient les professeurs désormais appelés professeurs de décret ou décretistes. Son autorité fut telle que les textes législatifs posterieurs, même les décrétales des papes, reçurent le nom d'Extra (decretum) vagantes (en abrégé $X)$ " ( $\mathrm{Ob}$. cit., p. 41-2 - grifos no original).

Pela alongada transcrição do lente parisiense, podemos perceber a enorme importância de Graciano e do seu "Decreto". para o Direito Canônico - e, de conseguinte, para a História do Direito Canônico e do seu Processo. Resulta, da lição de Jean Des Graviers, que Graciano foi antes de mais nada, um notável sistematizador de tudo o que, em matéria canônica, fora produzido até o seu tempo. Mas não-só: - como foi acentuado, o autor teve preocupações didáticas, e espírito pedagógico. 
É preciso, para bem compreendê-lo, ubicar Graciano em sua época, vale dizer, naquela quadra da Idade Média em que, mercê do surgimento da Universidade, há na Europa como que uma retomada da Cultura Greco-Romana. Há não-olvidar que, na mesma época em que Graciano sistematizava o Direito Canônico, Inério começava a se debruçar sobre os textos do Direito Romano, dando, aos estudos jurídicos, uma autonomia antes desconhecida...

A influência de Graciano e do Decreto, foi duradoura ao extremo. $O$ insigne professor Moacir Lôbo da Costa, em suas aulas nesta Casa, ensinava que, na Universidade de Coimbra, havia, na atualidade, os "decretistas" em oposição aos "decretalistas"

Mario Falco, antigo professor da Universidade de Milão, ao tratar das fontes do Direito Canônico, menciona o "Decreto" e o seu autor. Escreve, verbis:

"In teoria tutte le altre leggi della Chiesa dovevano essere conosciute direttamente e sigolarmente; in pratica ad esse si attingeva per il tempo piú antico ricorrendo alle collegioni private: il Decreto di Graziano, le Estravaganti di Giovanni XXII e le Estravaganti comuni.

Il Decreto, chiamato dall'autore Concordia discordantium canonum per l'intento propostosi da lui di togliere le contraddizioni fra $i$ vari testi, era un ampio trattato di diritto canonico, di liturgia, di teologia, compiuto probabilmente nel 1.140; Graziano, monaco camaldolese, maestro di "theologia practica externa" $e$ cioè di diritto canonico, nel monastero dei Santi Felice e Naborio a Bologna, vi raccolse, si può dire, tutto lo scibile canonistico del suo tempo, allegando come auctoritates per le sue tesi o discutendo o cercando de porre d'accordo decreti conciliari, costituzioni pontificie, passi della Bibbia, di padri della Chiesa, di scrittori ecclesiastici, di libri penitenziali, di scrittori secolari. Si potrebbe dire che l'opera è composta di una breve esposizione dell'autore e di uno strabocchevole apparato di note, le quali però non sono, come usa oggi, poste a piè di pagina, ma sono incorporate nel texto". 
(Vide Corso di Diritto Ecclesiastico, Padova, Casa Editrice Dott. Antonio Milani, seconda edizione aggiornata, 1935, volume primo, p. 18).

Algumas observações aqui se impõem. Em primeiro lugar, não há dúvida de que Graciano foi o primeiro sistematizador, científico, do Direito Canônico (Jean Des Graviers, ob. cit., p. 43, o chama... "le vrai Père du droit canonique"). Isto não elide, no entanto, que no "Decreto" haja elementos que não são estritamente jurídico-canônicos. Mais uma vez, é preciso atentar para a época em que viveu Graciano, vale dizer, a Idade Média: mesmo levando em conta que o Direito Canônico é, em última instância, um Direito revelado (a exemplo do Direito Hebraico e do Direito Muçulmano), seria inevitável que, numa obra medieval, os elementos litúrgicos para ficarmos só com este exemplo nele estivessem presentes...

Em segundo lugar, convém lembrar que o "Decreto" é uma das partes daquilo que, em 1500, o francês Chappius denominou Corpus Juris Canonici (conjuntamente com as "Decretais" de Gregório IX, o Livro Sexto de Bonifácio VIII, as "Clementinas", as "Extravagantes" de João XXII, e as "Extravagantes Comuns". Ora, o Direito Canônico teve vigência no Reino de Portugal, isto no denominado Período de Recepção do Direito Comum. Assim, não nos parece temerário afirmar que o "Decreto", importante na História do Direito Lusitano, o é, em termos mediatos embora, para a História do próprio Direito Pátrio!...

A corroborar o asseverado, leciona Nuno J. Espinosa Gomes da Silva:

"Temos, assim, no Corpus Iuris Canonici, compilações de caráter oficial e privado. De caráter oficial são as Decretais de Gregório IX, o Sexto e as Clementinas; de indole privada, o Decreto, as Extravagantes de João XXII e as Extravagantes Comuns.

Dada a vigência do direito canônico em Portugal, na época que examinamos, vão ser estas obras conhecidas, estudadas e aplicadas entre nós. Figuram elas principalmente o Decreto e as Decretais de Gregório IX nos testamentos e inventários das principais livrarias; e D. Dinis, em 1.309, estabelece que na nova 
Universidade exista um doutor in Decretis e um mestre in Decretalibus "per quorum Doctriã uberrimã crellici nostri regni jnstrui valleant..." (Ob. cit., pp. 162 e 163 grifos no original).

O "Decreto" de Graciano é, foi visto, uma das "compilações privadas" de Direito Canônico. E alguns problemas surgem a respeito dele. Jean Des Graviers, ob. cit., p. 43 e ss., assim os formula, de maneira sintética:

O "Decreto" é obra exclusiva de Graciano?

Uma primeira edição tão-pobre em textos de Direito Romano, não remontaria a 1.120 ?

Continha ela já a subdivisão em distinções e os títulos dos cânones?

- Uma edição mais completa, de por volta de 1.140 , é obra de Graciano e de sua equipe, ou deve ser atribuída a um continuador?

Tais problemas e as propostas para a sua solução foram discutidos no congresso que, em 1952, celebrou em Bolonha o oitavo centenário do Decreto. Não é impossível, adverte o autor francês, que Graciano, após anos de investigação, tenha se retirado "para o silêncio e a humildade do seu convento".

Outra questão interessante, é a da autoridade do "Decreto" O monge Graciano era, repitamos, um professor da Universidade de Bolonha. Ele não estava investido de autoridade legislativa. $\mathrm{E}$ isto, ainda de acordo com Jean Des Graviers, serviu de arma para os canonistas que, a partir do século $\mathrm{XV}$, repetem que o Decreto como as coleções dos antecessores do seu autor não passava de uma coleção privada. Mas raciocinar assim, é desconhecer o pensamento jurídico da Idade Média, argumenta o autor de Le Droit Canoninque, com o que, modestamente, concordamos. In totum. Vamos além: isto é querer ser kelseniano para uma época da História, que antecede Hans Kelsen de oito séculos!... como, com propriedade, ensina Jean Des Graviers:

"Raisonner ainsi, c'est sans doute se méprendre complètement sur la pensé juridique du moyen age et lui prêter des catégories intellectuelles postérieures de plusieurs siècles. Le Décret était une somme, un recueil de textes et d'arguments pour les maîtres et les étudiants, non pas un code". (Ob. e loc. cit. grifos nossos). 
Cremos que a primeira - e quiçá a mais árdua - cautela do estudioso da História, e pois da História do Direito, é a de, mentalmente, "se transportar" para a época pesquisada, o que implica, necessariamente, em que ele se desvencilhe das estruturas de pensamento da sua própria época.

A assertiva é válida, segundo cremos, em especial para a Idade Média, período em que inúmeros conceitos com que hoje lidamos diuturnamente (v.g., "O Estado", "Soberania" "Monopólio Estatal da Jurisdição", "Unidade do Ordenamento Jurídico", e outros), eram desconhecidos. Afora estes óbices, conceituais e terminológicos, outro há muito maior: - as diferenças axiológicas, que separam a nossa época do Medievo. Nós vivemos, com efeito, numa época "antropocêntrica", em que, numa curiosa volta a Protágoras de Abdera, "o homem é a medida de todas as coisas". E a Idade Média era "Teocêntrica"...

Após esta ligeira digressão, passemos a examinar a estrutura do "Decreto" A propósito, assim se insculpe o magistério de Mario Falco:

"Il Decreto è diviso in tre parti. La prima, divisa posteriormente in centouna distinctiones, tratta delle fonti del diritto (tractatus decretalium: dist. 1-20), poi del clero e ciò̀ della gerarchia e dell'ordinazione (dist. 21-59), della elezione, della consacrazione e della condizione giuridica dei prelati (dist. 60-90), della potestà ecclesiastica dei legati papali e dei primati (dist. 91-101). Nella seconda parte Graziano propone dei casi pratici, causae, dei vari campi del diritto e distingue in ciascuno di essi diverse questioni, relativamente alle quali vengono addote come si è detto, le varie auctoritates; la materia si può così raggrupare: le cause 10-14 trattano del diritto patrimoniale, le cause 16-20 del diritto dei religiosi, le cause 27-36 del diritto matrimoniale; del resto si tratta principalmente di diritto penale e di diritto processuale. Dal punto di vista giuridico interessano meno la trattazione de poenitentia, che è inserita nella terza questione della $33^{a}$ causa, ed ̀̀ divisa, come la prima parte, in distinzione ed in canoni, e la trattazionne de consecratione, che costituisce la terza ed ultima parte del Decreto, si occupa della 
consacrazione delle chiese, dell'eucarestia, dei giorni festivi, del battesimo e della confermazione, ed è divisa essa pure, come la prima, in distinzioni ed in canoni". (Ob. cit., p. 18 e 19 - grifos nossos).

Deixaremos de banda a maneira de citar os textos do "Decreto" Apenas diremos que os trechos da exposição pessoal de Graciano foram, pelos glosadores, chamados de "paragraphi": ao passo que os modernos os chamam "dicta Gratiani"

Discípulo importante de Graciano foi Paucapaléia, o qual veio a acrescentar textos à obra do seu mestre. Estes textos são denominados "Paléias"

Encerraremos esta parte do presente trabalho, com algumas remissões à obra de José Antonio Martins Gigante, antigo professor de Direito Canônico do Seminário Conciliar de Braga, e autor do livro Instituições de Direito Canônico (Braga, Escola Tip. Da Oficina de São José $3^{\mathbf{a}}$ ed., 1955).

O autor faz uma interessante e erudita análise das condições em que se encontrava a Europa Ocidental, e com ela a Igreja Católica, à época em que surgiu o "Decreto". Julgamos de interesse transcrever, in totum, as suas palavras a respeito. Escreve Martins Gigante, verbis:

"Falou-se acima das dificuldades e confusões que trouxeram os três factos históricos já também referidos. Dificuldades essas que não desapareceram com as falsificações das coleções pseudo-Isidorianas nem com as tentativas da reforma.

Nos séculos IX e X surgiram novas e mais graves dificuldades provenientes principalmente do direito intitulado "da igreja própria", da investidura feudolaical, da simonia e concubinato dos clérigos. Por isso a S. Sé no século XI lançou mão duma reforma universal, prestando óptimo auxílio os monges cluniacenses. Esta reforma, embora tivesse início antes, intitulou-se de Gregório VII por este ser o seu principal paladino.

Todas as colecções deste periodo são: a-) privadas, exceptuando algumas reformatórias levadas a cabo sob os auspícios dos $R$. Pontífices; b-) sistemáticas, tanto de 
cânones quanto de decretais e leis civis tiradas do Direito Romano e das capitulares dos reis Francos.

Como a reforma gregoriana não atingisse a sua finalidade com o rigor que se pretendeu, pelo facto de os reformadores atacarem as instituições jurídicas já inveteradas na Gália, norte da Itália e Germânia, houve varões prudentes, como Ivo Carnotense, que escolheram um meio termo, compilando os textos reformatórios com os impugnados, mas necessários.

Dest'arte surgiram as colecções da concordância dos cânones, porém esta era externa, enquanto justapunha os textos diversos e opostos, segundo a ordem sistemática, todavia, a oposição interna continuou, porque os cânones em si não se conciliavam nem se estabeleceu a unidade. Com efeito, para isso não era suficiente o trabalho do compilador, mas exigia-se um estudo sério e aturado de todo o direito e sobretudo dos princípios fundamentais do Direito Canônico. Esse trabalho foi levado a efeito pela Teologia escolástica $e$ pelo estudo renascente do Direito Romano.

Aquela forneceu a arte de distinguir e conciliar os textos verdadeira ou aparentemente opostos $e$ o estudo renascente de Direito Romano esclareceu a ordem jurídica estabelecida pelo Direito Romano clássico e forneceu a clareza e disposição cuidada dos conceitos jurídicos.

Assim estava aberto o caminho que Graciano trilhou, dando ao público a sua obra admirável o "Decreto", que iniciou a idade áurea do Direito Canônico e ciência canônica." (Ob. cit., volume I p. 24 - grifos no original).

Cremos que a alongada transcrição se justifica, in totum, num trabalho histórico-jurídico do tipo do presente. O Direito é - convém enfatizá-lo sempre, na esteira de Miguel Reale - um fenômeno histórico-cultural. A historicidade lhe é 
ínsita. Assim, é preciso perquirir da ambiência histórica em que surgem os monumentos jurídicos, para bem os conhecer. A esta historicidade não refoge, como é elementar, o Direito Canônico. Daí, a oportunidade da transcrição integral da lição do ilustre mestre bracarense.

Percebemos que, para o autor português ora seguido, o monge Graciano, ao elaborar o "Decreto", dispunha, por assim dizer, de um "instrumental de trabalho" que não fora conhecido dos canonistas de épocas anteriores. Convém enfatizar, a propósito, que a sistematização científica do Direito Canônico é contemporânea do ressurgimento, em Bolonha, dos estudos romanísticos, a partir de Irnerius.

Nunca é demais lembrar que, em termos da Idade Média, é preciso pensar em "um e outro Direito, o Romano e o Canônico" (Utrunque Jus). O Direito Romano, como bem lembra Nuno J. Espinosa Gomes da Silva, era a Lex Saeculi da Igreja Católica; Igreja que havia recolhido o legado da Cultura Greco-Romana, e que, no caos dos primeiros séculos do Medievo, remanescera ainda de acordo com Nuno Espinosa a única grande realidade institucional... ora, convivendo em Bolonha, romanistas e canonistas, forçosamente, haveriam de exercer influência, uns sobre os outros. Aliás, escreve José Antonio Martins Gigante:

"João Graciano nascido nos meados do século XII, provavelmente em "Chiusi", camaldulense e mestre de Teologia e de Direito Canônico no mosteiro de S. Felix e Nabor em Bolonha, vendo o cuidado de Irnerio em promover o estudo do Direito Romano, lançou mãos à obra com o fim de fazer uma nova colecção canónica a que ele deu o título de "Concordiam discordantium canonum", porém, provavelmente por ter semelhanças com o Decreto de Burchardo e de Ivo Carnotense, denominaram-na depois "Decreto de Graciano" (Ob. e vol. cit., pp. 24 e 25 - grifos no original).

Aduz o canonista lusitano:

"Parece haver sido escrito cerca do ano 1140, servindo de manual de direito no foro e de compêndio nas escolas, logo que foi publicado. 
É uma colecção privada e por isso a doutrina $e$ sumários tinham a autoridade dum varão douto, os canônes autênticos conservavam a sua força jurídica universal e particular e os espúrios tinham força de lei em virtude do costume". (Ob. e loc. cit. - grifos no original).

Consoante já tivemos ensejo de observar, a obra de Graciano, produzida no século XII, é um reflexo da sua época, no que diz respeito a nãoexistir, ainda, uma separação precisa entre o jurídico e o não-jurídico. A propósito, leciona Martins Gigante, ao tratar da matéria contida no "Decreto":

"O Decreto, além de toda a legislação relativa à disciplina da Igreja, contém questões dogmáticas $e$ morais propostas conforme as exigências do seu tempo, em que as disciplinas teológicas não estavam cuidadosamente separadas. Graciano aproveitou documentos de quase todas as colecções antecedentes, ou seja, cânones penitenciais, dos concílios universais $e$ particulares, decretais pontifícias, capitulares episcopais, textos da S. Escritura e dos SS. Padres, leis civis romanas e bárbaras." (Ob. e loc. cit. grifos nossos).

Ao abordar o método de que se valeu Graciano, escreve o canonista português:

"O autor pretendeu não-só coleccionar e dispor os documentos, mas ainda conciliá-los, estabelecendo a unidade interna. Por esta razão, à testa de cada capítulo, expõe a sua opinião resumidamente, que prova com argumentos tirados da autoridade (documentos) $e$ cânones" (Ob. e loc. cit. grifos nossos). 
Salientemos, neste passo e por oportuno, que o "argumento de autoridade" desempenhou um grande papel na Cultura do Medievo. O célebre magister dixit é incindível desta quadra da História do Pensamento e também da História do Direito. Façamos justiça à Idade Média, no entanto, ao consignar que ela recebeu o "argumento de autoridade" dos antigos. Neste sentido, convém lembrar o "Tribunal dos Mortos" da Jurisprudência Romana...

No que tange à divisão da obra, damos a palavra ao até aqui seguido José Antonio Martins Gigante:

Ensina este autor, verbis:

"O Decreto foi dividido materialmente pelo autor $e$ formalmente pelos decretistas e editores em três partes.

A $1^{a}$ contém 101 Distinções, subdivididas em cânones, onde, além da introdução geral acerca das fontes, trata das pessoas e ofícios eclesiásticos. Modo de citar: c.1 D.I ou 1.

A $2^{a}$. parte contém 36 Causas, subdivididas em questões, excepto a $3^{a}$. questão da $33^{a}$., que está dividida duma maneira especial, como se verá. Nesta o autor segue um método casuístico, porquanto em cada causa propõe um caso prático para cuja solução apresenta várias questões que são resolvidas com os cânones. Modo de citar: c.l C.1 qu.1.

A causa $33^{a}$., questão $3^{a}$., é uma espécie de tratado especial acerca da penitência, à imitação dos livros penitenciais, e do livro XIX do Decreto de "Burchardo": a referida questão $3^{a}$ está subdividida em 7 Distinções $e$ estas em cânones. Modo de citar: c.l D.1, De poenit.

A parte $3^{a}$ denominada "De consecratione", é destinada à liturgia. Foi dividida por um discípulo de Graciano, conhecido por "Paucapália" em Distinções e estas em cânones. Modo de citar: c.l D. e de consecrat." (Ob. e loc. cit. - grifos no original).

Como podemos observar, o ilustre professor de Braga registra o nome do discípulo de Graciano, como "Paucapaléia" É encontradiça, também, a grafia 
"Paucapália" Da primeira se utilizava o insigne professor Moacir Lôbo da Costa. Aliás, a grafia exata dos nomes das pessoas, na Idade Média, é uma questão tormentosa. Barbara W Tuchman, ao escrever sobre o século XIV, anota a dificuldade em pauta:

" $O$ antigo regente, agora Carlos $V$, nomeou para comandar a cruzada um estranho capitão novo, tãoduro quanto o seu nome bretão, que os franceses escreviam de Clequin ou Kaisquin ou Clesquy, até que a fama o fixou em Bertrand Du Guesclin." (V. Um Espelho Distante, (O terrível século XIV) - tradução de Waltensir Dutra, Rio de Janeiro, José Olympio, 1989, p. 208 grifos nossos).

Em inúmeras outras passagens do livro dessa notável historiadora, é perceptível a mencionada imprecisão gráfica dos nomes, durante a Idade Média. Assim, e verbi gratia, o inglês Sir John Hawkwood, comandante da "Companhia Branca", era chamado, pelos italianos, de "Giovanni Acuto" (ob. cit., p. 237).

Os idiomas nacionais ainda não haviam surgido, à época de Graciano (anterior ao século XIV). Escrevia-se em Latim. Mas, como observa Nuno J. Espinosa Gomes da Silva, num Latim que iria horrorizar os humanistas no Renascimento.

Feita esta ligeira digressão, fixemo-nos na grafia "Paucapaléia" para o nome do principal discípulo de Graciano.

Martins Gigante assim finaliza os seus comentários sobre o "Decreto":

"No Decreto de Graciano distinguem-se: a-) "Dicta Gratiani" ou seja, as palavras por que se exprime a sua opinião; b-) "Auctoritates" ou "canones", que são os textos legais; c-) "Summaria" "rubricae", por que a matéria difusa nos textos se sintetiza; $d$-) "Pália", isto é, cerca de 500 cânones omissos por Graciano $e$ introduzidos por "Paucapália" e outros Decretistas.

Importancia $O$ Decreto de Graciano foi jurídica $e$ cientificamente muito importante. Notabilizou-se pela: a-) amplidão da matéria; b-) concordância sistemática 
dos cânones; $c$-) prudente moderação em conciliar os textos reformatórios com os opostos.

Por esta razão, ainda que privado, impôs-se na prática administrativa e judicial. Espalhou-se de Bolonha com o carácter de guia autorizado das escolas canónicas com grande proveito para a unidade didáctica.

Os R. Pontifices tiveram o cuidado de evitar interpolações e Gregório XIII em 1582 promulgou uma edição corrigida que julgou reproduzir o texto genuíno. Apesar disso nunca obteve o carácter de coleç̧ão autêntica." (Ob. e vol. cit., p. 26 grifos no original).

IV - A difusão da obra de Graciano os "Decretistas"

O labor do nome Graciano culminou com a estabilização do Direito Canônico. Obra didática, como visto retro, o "Decreto" difundiu-se, com celeridade, por toda a Europa. Como tivemos oportunidade de verificar, El-Rei D. Dinis determinou que, na recém-criada Universidade portuguesa, houvesse um professor do Decreto.

Quem eram, pois, os "Decretistas"? Define-os Martins Gigante como "os mestres e escritores que interpretaram o Decreto de Graciano ou ensinavam o Direito Canônico nas escolas". (Ob. v. e loc. cit.).

O mesmo autor afirma que os "Decretistas" assim se denominavam, em oposição aos "legistas" - estes, professores de Direito Civil (Romano, portanto...).

Sobre o ensino no Medievo matéria que já abordamos retro ensina Martins Gigante:

"Na Idade Média havia várias espécies de escolas, isto é, as das igrejas Catedrais, das Colegiadas e dos Mosteiros. Nelas, além das artes liberais, ensinava-se a Teologia e o Direito Canônico. Existiam algumas destinadas sómente ao estudo do direito v.g. a de 
Bolonha que apenas se dava ao estudo do Direito Romano, etc.

Todas essas escolas eram particulares e entre si separadas $e$ independentes. Pelo ano 1200 os mestres de Paris constituíram uma sociedade à maneira de direito corporativo germânico, dando origem ao primeiro estudo geral ou Universidade dos estudos.

Quase nessa ocasião e pelo mesmo motivo constituiu-se a Universidade de Bolonha, a que seguiram outras fundadas pela S. Sé ou pelo imperador.

$O$ método seguido nessas escolas foi o exegético $e$ escolástico.

As lições baseavam-se num livro de texto, tendo-se em grande consideração e reverência a doutrina recebida da tradição.

Os mestres que nelas faziam a leitura do texto e o explicavam ou comentavam diziam-se "lentes" $e$ os compêndios das suas leituras denominavam-se "preleções", que nos assuntos mais dificeis tomavam o nome de "repetições", por se explicarem mais do que uma vez.

Os mestres que escreviam as "glossas" ou explicações mais extensas tinham o nome de "expositores" ou "glossatores"

As glossas mais antigas eram "interlineares" ou seja, escritas entre as linhas do texto e depois "marginais": o conjunto de muitas glossas constituía o "apparatus glossarum"

Foi delas que provieram as "summas", quer dizer, comentários independentes do texto e dispostos sistematicamente" (Ob., v. e loc. cit., bem como p. 21 grifos no original). 
Pela repercussão e pelos desdobramentos do "Decreto" verificamos que, além da sua importância intrínseca, de primeira obra de sistematização científica do Direito Canônico, desempenhou ele um papel de enorme importância, em toda a Europa, na subseqüente evolução dos estudos jurídico-canônicos.

V - O processo em Graciano

José Antonio Martins Gigante, em suas Instituições de Direito Canônico, em Notas Históricas, leciona:

"Embora já antes do Decreto de Graciano vários escritores de colecções canônicas e autores de compilações de leis apresentassem e colocassem no seu lugar o Direito Canônico-judicial, v. g. Bernardo Papiense, todavia, $o$ direito processual foi sistematicamente redigido nesse Decreto, passando depois na sua substância para as Decretais de Gregório $I X$, que nos títulos XXIX, XXI, XLI e XLII do livro I e em todo o livro II encerra o direito processual geral, e, sobretudo o especial contencioso e as principais questões do criminal, suprindo no livro $V$ o que falta no II, relativamente ao direito processual criminal" (Ob. cit., v. III, p. 1 - grifos nossos).

O ilustre professor Carlos Silveira Noronha subordinou a sua dissertação de mestrado nesta Casa ao título Perfil Histórico-Dogmático da Sentença Civil. E, nela, dedica algumas páginas ao Decreto de Graciano.

Escreve o professor do Rio Grande do Sul, verbis:

"Na doutrina historiográfica, há autores que dividem a história do direito canônico em cinco períodos distintos: o período do "ius vetus", do início do Cristianismo no século I até o Decreto de Graciano (ano 1140); o segundo, do "ius novum", de Graciano ao Concílio de Trento (ano 1564); o terceiro, do "ius novissimum", do concílio tridentino ao primeiro "Codex 
Iuris Canonici" de 1917; o quarto, o período transcorrido entre a primeira codificação oficial $e$ o "Codex Iuris Canonici" de 1983, em vigor; e o quinto, a partir desta última codificação (363). É um critério temporal-formal fixado em períodos temporais que nem sempre se conformam com o desenvolvimento material da ciência canônica. Outros há que dividem-na tendo a obra de Graciano como marco divisor, isto é, analisam a canonística antes de Graciano e depois de Graciano (364)". (Ob. cit., São Paulo, Maio de 1992, p. 240).

Percebemos que, quer seja adotada a divisão em cinco períodos, quer em dois, o "Decreto" de Graciano remanesce como um marco fundamental da História do Direito, e pois, da História do Processo Civil.

O processualista sulino esposa, no entanto, a divisão tríplice adotada pela ilustre cátedra, e pela qual, na História do Direito Canônico, há considerar um Período de Formação, das origens ao século XI; um Período de Estabilização, do século XII ao século XV; e um Período de Renovação, do século XVI aos nossos dias. Justifica o professor Carlos Silveira Noronha a sua preferência:

"Este critério parece ser mais lógico, eis que harmoniza o elemento formal do decurso do tempo com o elemento substancial da evolução e progresso do direito canônico" (Ob. e loc. cit.).

Julgamos que, além do motivo dado pelo autor, um outro há, a justificar a divisão em três períodos da douta cátedra. Trata-se do momento em que a obra de Graciano foi produzida. Trata-se, em síntese, do século XII, fundamental para a Cultura do Ocidente. A sistematização do Direito Canônico foi um fenômeno que coincidiu, no tempo e no espaço, com a sistematização do Direito Romano. E ambas foram coincidentes com o surgir da Universidade no Ocidente Europeu!... Foi no glorioso século XII que, como sempre, na orla do Mar Mediterrâneo, os homens voltaram a sentir a "vocatio" do Universal. Este "chamamento" legado grecoromano, ficara momentaneamente "apagado" E o seu ressurgir é incindível do "Estudo Geral" 
A leitura de parte da dissertação de Carlos Silveira Noronha, permitiu que soubéssemos que Graciano se chamava "Graciano de São Félix e Nabor" Aduzimos que este deveria ser o seu nome monástico, uma vez que o autor do "Decreto" era um integrante do "Clero Regular". O seu nome laico, de acordo com o que vimos retro, era "João Graciano"

O autor aqui seguido enfatiza que, na Concordia Discordantium Canonum, Graciano separou o Direito Romano do Canônico, destacando o segundo da Teologia, o que constituiu uma inovação. E que, no Decretum, as matérias eram dispostas ordenadamente, cousa que não ocorria nas compilações anteriores.

Segundo Noronha, graças aos dicta Graciani, houve uma uniformização do Direito Canônico, passando os tribunais a aplicá-lo com maior facilidade. O original do Decretum, de acordo com o mesmo autor, jamais foi conhecido. A primeira edição impressa veio a lume em 1500 . O prestígio da obra, determinou que o Romano Pontífice nomeasse uma comissão, formada pelos corretores romani, para aferir qual seria a cópia correta. $\mathrm{O}$ texto corrigido, considerado oficial, veio à luz em 1582. De passagem, é necessário observar que, em se tratando de uma coleção particular, foi o Decretum Gratiani extraordinariamente honrado pelo Papado...

Do ponto de vista estritamente processual, escreve sobre o "Decreto" o já-citado professor do Rio Grande do Sul:

"Assim, na sua condensação de textos e compilações, o Decreto apresentava duplo aspecto, pois se de um lado fazia uma reprodução dos princípios que na época de Graciano governavam o processo; de outro, constituíase no documento que reunia até aquele momento todos os elementos constitutivos dos princípios admitidos no ultramilenar espaço de tempo anterior e que serviriam de base à renovação das instituições canônicas que em futuro breve se iniciaria. Formava a obra verdadeiro liame que ligava o passado e o presente da canonística" (Ob. cit., p. 242 grifos nossos). 
Das três partes em que era dividido o "Decreto", a segunda curava das causas judiciais, cuidando - escreve Noronha - "das três fases distintas da função de conhecimento, da fase recursal e da estrutura humana necessária para o fundamento do juízo: "iudex", advogado, procurador e auxiliares, dentre estes, o encarregado da citação e da atestação da revelia do demandado, fazendo ainda as distinções entre "verus iudex" pelos critérios jurídicos (imparcialidade), e "bonus iudex", por critérios morais (garantias morais de seriedade e independência), respectivamente, como requisitos de que deveria estar exornada a pessoa do juiz para obter-se uma boa judicatura". (Ob. e loc. cit.).

Trinta e seis "causas" foram elencadas por Graciano, cada uma delas divididas em "questões", e as "questões" em capítulos.

Na obra de Graciano, o processo não foi a matéria jurídica com maior desenvolvimento. $\mathrm{E}$ isto em função de, ao tempo do genial sistematizador, nãohaver, ainda, uma separação nítida entre o campo de incidência das disciplinas teológico-apostólicas e o da processualística. Além disto, observa Noronha, em matéria processual, tanto a legislação quanto a doutrina canônicas, ainda se encontravam num estado embrionário. Ainda assim, a obra é rica no que tange ao processo, se comparada com as anteriores. Nestas, só havia normas de Direito Romano e de Direito Germânico, transportadas para o Ordenamento Jurídico da Igreja.

No processo de conhecimento, o "Decreto" contemplava as três fases da Introdução, da Instrução e da Definição. Na Introdução estavam disciplinados o libelo, a citação, a contestação da lide e, depois desta última, o ato formal da litis contestatio. Afirma o professor Noronha que a litis contestatio "não diferia, quanto ao conteúdo e efeitos, do mesmo ato praticado perante o Direito Romano Justinianeu, isto é, servia apenas para constatar-se a pretensão do autor invocada no libelo, a contrariedade do réu, ou a sua aquiescência ao pedido do autor (confessio in iure), ou, ainda, a revelia do demandado" (Ob. cit., pp. 243 e 244). A litis contestatio, destarte, servia apenas para fixar os limites do litígio. Não influía na sentença.

$\mathrm{Na}$ Instrução, eram considerados os vários meios de prova, em especial, as provas orais do juramento e testemunhal. As provas orais eram muitíssimo valorizadas, partindo Graciano dos conteúdos do Jus Divinum que as informavam: - os sujeitos da prova teriam as exatas medidas de moralidade e de pecado que as suas declarações poderiam conter. 
Na Definição, ubicava-se a sentença. O "Decreto" trata pouco desta matéria. Mas traça algumas regras, demonstrando preocupação com os conteúdos que deviam estar presentes na sentença. Esta era um documento destinado a refletir a verdade processual, bem como "uma perfectível vontade substancial". (Ob. e loc. cit.). Tendo em mira tais resultados, Graciano estipulava alguns requisitos de natureza processual, a serem observados na sentença. Em primeiro lugar, fixou Graciano a Pluralidade de Graus de Jurisdição, que como é sabido haveria de remanescer como um dos princípios capitais do processo canônico. Esta pluralidade iria se articular com um outro princípio básico, o da Tríplice Sentença Conforme (exigência de três julgamentos no mesmo sentido, para se chegar à res judicata).

De outra banda, Graciano estabelecia Alguns Requisitos de Ordem Espiritual e Moral para a sentença. Carlos Silveira Noronha assevera que tais princípios "se encontravam particularmente vivos no contexto da canonística" E aduzimos que tais princípios Deveriam Estar Particularmente Vivos Hoje... são eles: Judex debet eam ferre cum mentis tranquilitate non in furore; Iniusta (sententia) nocet potius ferendi quam patienti; Iniqua sententia est revocanda.

Algumas regras de ordem substancial deviam ser observadas pelo juiz, ao proferir a sentença: - Non secundum propriam voluntatem sed secundum leges (sententia) est proferenda; Non est danda sententia nisi post plenam investigationem veritatis. Chamamos, na esteira de Noronha, particular atenção para este cânone: A sentença não devia ser proferida senão depois da plena investigação da verdade; "ergo" depois de esgotados todos os meios probatórios capazes de revelar a verdade dos fatos controvertidos. Noronha vislumbra com acerto, nessas recomendações no "Decreto" ao juiz, O Conceito de Justiça da Sentença. Esta haveria de se lastrear nos conteúdos moralistas espiritualistas em torno dos quais gravita a ciência canônica. Também obra acertadamente o mestre sulino, ao afirmar que Graciano admitia o requisito da Certeza Moral na elaboração da sentença.

Dispunha o "Decreto" que a sentença deveria ser prolatada por escrito. Salientemos que "juiz" era, normalmente, $O$ Bispo, cujo tribunal, a Episcopalis Audientia, foi renovado por Graciano. Eram atos do juiz o decretum, com o qual o processo era ordenado e desenvolvido, e as sententiae, das quais havia as definitivae e as interlocutoriae.

A propósito de umas e outras, leciona Carlos Silveira Noronha: 
"As primeiras eram impugnáveis pela "appellatio", tanto as injustas ou iníquas, quanto as nulas, pois, segundo a doutrina de Liebman, por longo tempo, tanto no Direito Romano, quanto no direito medieval, as sentenças inquinadas de "errores in iudicando" como de "errores in procedendo": eram passíveis do recurso de apelação (367), completando-se a assertiva com Della Rocca, para quem a "querella nullitatis", para atacar a sentença nula, só teria surgido da confluência da "exceptio nullitatis" das Decretais com a "actio nullitatis" do processo comum (368).

A sentença interlocutória era apelável no "Decretum Graciani" por disposição expressa (c. 38. q. 6 C.II), que a identificava com a sentença definitiva (369). Aliás, tal posição assumida na dita compilação não era de se estranhar, porque essa era a regra no processo canônico, desde que, em contacto com o processo germânico, teve o seu procedimento dividido em fases estanques "termini" ou "stadia" encerrando-se cada "terminus" com um provimento judicial, que no processo romano chamava-se "interlocutio" e no processo canônico passou a denominar-se "sententia interlocutoria"" (Ob. cit., pp. 246 e 247 grifos no original).

O prazo, qualquer que fosse a sentença (definitiva ou interlocutória), para a interposição da Appellatio, era o de dez dias. O recurso era dirigido à autoridade imediatamente superior àquela que havia proferido a sentença. Mas havia, per saltum, o apelo dirigido, diretamente, à Sé Apostólica (Rota Romana e Supremo Tribunal da Assinatura Apostólica), bem como ao Sumo Pontífice.

A propósito da influência do processo germânico sobre o processo canônico, apontada acima, é preciso lembrar que a Idade Média foi, por excelência, o palco de uma riquíssima interpenetração de culturas. Em termos sintéticos, neste período da História, o legado greco-romano, bafejado pelo Cristianismo, entrou em 
contato com os "bárbaros" E, a Igreja era repitamo-lo! - a única grande realidade institucional a subsistir...

Contra as sentenças definitivas, válidas e transitadas em julgado, o "Decreto" conhecia a Restitutio in Integrum.

Quanto à "tríplice conforme" para a configuração do trânsito em julgado, devemos salientar haver ela Sobrevivido a Graciano, só sendo alterada pelo Código Canônico de 1917 (do Papa Bento XV), que instituiu a "dupla conforme"

VI - Conclusões

A obra de Graciano foi, como já se tornou um lugar comum afirmar, um divortium aquarum, um genuíno "espigão divisor" na evolução do Direito Canônico. Na evolução desta disciplina, há o Antes e o Depois de Graciano. O genial monge está, para os estudos canonísticos, assim como Irnerius está para os estudos romanísticos. Pedimos vênia pelo uso da linguagem matemática, para enunciar a presente comparação. Desejaríamos, no entanto, fazer uma observação pessoal, que não tem, em absoluto, qualquer pretensão à originalidade. É ela, ademais, formulada sub censura dos mais doutos. Ei-la: - Estamos convencidos de que o labor dos primeiros romanistas de Bolonha, foi mais árduo que o dos canonistas. E isto porquanto Irnerius e os seus continuadores, até a Magna Glosa de Arcúsio, Se Debruçaram Sobre Um Objeto de Estudo, Até Então, e Para Eles, Totalmente Desconhecido. Este objeto era constituído, como é intuitivo, pelos textos do Direito Romano Justinianeu, dos quais estavam, os estudiosos do Medievo, separados por séculos... encontraram, Irnerius e os seus continuadores, uma primeira barreira, áspera ao extremo, para transpor: o idioma. Pois que, como observado retro, o Latim Medieval era bastante diferente do Latim do Corpus Juris Civilis. A "glosa" é a personificação desta enorme barreira. Outras havia, no entanto: eles estudavam um Direito feito para uma realidade política desaparecida de havia muito... e assim por diante.

Os canonistas com a inclusão de Graciano não toparam com tais, e com tamanhas dificuldades. Desde o surgimento da Igreja Católica, o Direito Canônico era um "Direito Vivo". com tudo o que daí decorre. 
Feita esta pequena observação, e para concluir, afirmamos, com Fernando Della Rocca, que o "Decreto" de Graciano constitui "più que la premessa od il punto di partenza dell'evoluzione che poi avrebbe dato al processo la sua autonomia, la prima occasione per formasi, nel campo dei canonisti che seguirono l'impulso di Graziano, di una conscienza e di un travaglio sui quali si dovette bem presto basare la communis opinio che la Chiesa aveva necessità di un própio ordinamento processuale" (In Saggi di diritto processuale canonico, Padova, CEDAM, 1961, p. 218, apud Aloísio Surgik, Compêndio de Direito Processual Canônico, Curitiba, Edições Livro É Cultura, $1^{\text {a }}$ ed., 1988, pp. 23-4).

Com uma derradeira observação, queremos finalizar este ligeiro exercício: com o seu inigualável estilo, costuma afirmar o professor Miguel Reale que o Ocidente é uma síntese do Logus da Filosofia Grega; da "Voluntas" do Direito Romano, e da "Caritas" do Cristianismo. Acrescentaríamos, às sábias palavras do autor de Horizontes do Direito e da História, que a Igreja Católica, após a queda do Império do Ocidente (ano de 476 d.C.), teve um papel fundamental, no que tange a abrandar a rudeza dos costumes dos povos germânicos. Ao direcionar e disciplinar a belicosidade dos teutos, a Igreja, v. g., contribuiu para o surgimento da Ordem da Cavalaria.

Por outras palavras, a Igreja - e de conseguinte, o seu Direito contribuiu para o resgate do "humanismo" (não-confundir com o sentido Renascentista da palavra) que perecera com Roma.

Aloisio Surgik, ao tratar desta matéria, escreve, verbis:

"O conceito de justiça coloca-se sob o elemento da charitas, sendo assim uma humanitas muito espiritualizada, no dizer de Fernando Della Rocca (28), operando-se a transformação de charitas na aequitas como corretivo da justiça: ubi charitas non est non potest esse iustitia". (ob. cit., p. 21). 
Este "humanismo cristão", ou melhor, necessariamente cristão, presente no "Decreto" de Graciano, é um valor atemporal da Igreja Católica, Apostólica e Romana. Ele estará presente no lema do grande Papa Pio XII: - Opus Justitiae Pax.

$$
\begin{aligned}
& \text { "Finis Operae, } \\
& \text { Deo Gratia" } \\
& \text { Urbs Paulopolitana, }
\end{aligned}
$$

São Paulo, 12 de novembro de 1993.

VII Bibliografia

ARENDT, Hannah. Entre o passado e o futuro. Tradução de Mauro W. Barbosa de Almeida. $3^{a}$ ed. São Paulo : Editora Perspectiva S.A., 1992.

CAETANO, Marcello. História do Direito Português. Lisboa : Editorial Verbo, 1981. v. I

CONAN DOYLE, Sir Arthur. A Companhia Branca. Tradução de Hulda Chaves Lenz César. São Paulo : Edições Melhoramentos, s/d.

DES GRAVIERS, Jean. Le Droit Canonique. Paris : Presses Universitaires de France, deuxième édition mise a jour, 1967.

FALCO, Mario. Corso di Diritto Ecclesiastico. Padova : Casa Editrice Dott. Antonio Milani, seconda edizione, ristampa aggiornata, 1935. Volume primo.

GARCIA, Antonio Garcia y. Estudios sobre la Canonistica Portuguesa Medieval. Madrid: Fundacion Universitaria Española, 1976.

GIGANTE, José Antonio Martins. Instituições de Direito Canônico. $3^{\mathrm{a}}$ ed. Braga : Escola Tip. De Oficina de São José, 1955.

GILISSEN, John. Introdução Histórica ao Direito. Tradução de A. M. Hespanha e L. M. Macaísta Malheiros. Lisboa : Fundação Calouste Gulbenkian, 1988.

LOYN, H. R.. Dicionário da Idade Média. Tradução de Álvaro Cabral. $2^{\mathbf{a}}$ ed. Rio de Janeiro : Jorge Zahar Editor, 1991.

NORONHA, Carlos Silveira. Perfil Histórico-Dogmático da Sentença Civil.

Dissertação de Mestrado apresentada aos Cursos de Pós-Graduação da Faculdade de Direito da Universidade de São Paulo. São Paulo, maio de 1992.

REALE, Miguel. Lições Preliminares de Direito. $16^{a}$ ed. São Paulo : Editora Saraiva, 1988. 
SILVA, Nuno J. Espinosa Gomes da. História do Direito Português. Lisboa : Fundação Calouste Gulbenkian, 1985. v. I

SUSRGIK, Aloísio. Compêndio de Direito Processual Canônico. $1^{\mathrm{a}}$ ed. Curitiba : Edições Livro É Cultura, 1988.

TUCHMAN, Barbara W. Um Espelho Distante. Tradução de Waltensir Dutra. Rio de Janeiro : Livraria José Olympio Editora S.A., 1989. 